\title{
Secondary school socio-cultural context influencing ICT integration: A case study approach
}

\author{
Shanti Divaharan \\ Nanyang Technological University \\ Lim Cher Ping \\ The Hong Kong Institute of Education
}

\begin{abstract}
This paper proposes the use of activity theory and multi-level activity systems as a framework to analyse the effectiveness of ICT integration in Singapore secondary school classrooms. Three levels of activity systems are developed to study the effectiveness of ICT integration at the classroom: the classroom activity system, the department activity system and the school activity system. A multiple case study approach with three secondary schools in Singapore was adopted to provide in depth understanding of the socio-cultural factors that affect ICT integration in the classrooms. The findings show that schools need to function as learning organisations to be adaptable to changes, especially rapid changes brought about by technology integration in curriculum. To be successful learning organisations, schools need a curriculum focused, over-arching ICT goal to provide clear direction to the key players - teachers, HOD/ICT and instructional program HODs in the school. The management approach to ICT integration in the school should be through distributed leadership. While the school principal sets the tone for the school vis-à-vis modelling curriculum focused integration, providing encouragement to teachers and support for the HODs plans, the role of the HOD/ICT should be to ensure the relevant ICTenabled infrastructure and implementation procedures are in place.
\end{abstract}

\section{Introduction}

Information and communication technology (ICT) integration, according to policy makers, takes place when teachers know how to incorporate and use ICT to teach in the classroom (Cuban, 2001; Ertmer, 1999). This predicate assumes that once the teachers know how to use ICT to teach, the students would become learners engaged in using ICT as a tool to learn. However, other research findings report the contrary.

The actual situation is that although computers and software are widely available, little change has taken place in the way teachers teach in the classrooms (Cuban, 1993; OTA, 1995). Teachers in schools seem to be unable to optimise the use of ICT for teaching (Stetson \& Bagwell, 1999; Zhao \& Cziko, 2001). Morrison and Lowther (2002), Gooden (1996), Morton (1996) and Hadley and Sheingold (1990) suggest that computers have become an 'add on' tool to the classroom learning environment, just as textbooks are an 'add on'.

Dias's (1999) alternative view to ICT integration is that it should be used in a seamless manner as part of the daily learning process that takes place in classrooms. Means and Olson (1997) and Ertmer (1999) define ICT integration as the use of technology to 
promote students' learning by challenging them with complex and authentic tasks and learning, in a collaborative environment where ICT furnishes students with information to support their inquiry and investigation process. The emphasis is on the learning context and ICT integration should be analysed in the context in which it is being integrated.

The purpose of this research study is to determine the factors and the interaction of factors which support teachers' integration of ICT to engage students in the learning process. With the advent of ICT integration in the education system, many researchers have embarked on studies to examine the effect of ICT on students' learning. That is, whether ICT has been integrated effectively, what are the factors that encourage ICT integration, and what are the factors that are a barrier to ICT integration.

\section{Factors that affect effective ICT integration}

One of the key factors that had a considerable influence on the teachers' decision to integrate ICT was availability of time. Lack of time was identified as a barrier to ICT integration (Dias, 1999; Wang \& Chan, 1995). Ertmer (1999) and Manternach-Wigans (1999) also claimed that teachers' perception of lack of time for them to learn and integrate technology into the classroom is a contributing factor that inhibited ICT integration. Jaber and Moore (1999) and Martin (2000) indicated in their findings that teachers need to be given time to plan and to integrate ICT into the curriculum in order to achieve substantial effective integration. Inadequate access to technology and not having enough time to access technology to be familiar with it affected teachers' competency and comfort level for ICT use (Dawson \& Heinecke, 2004; ManternachWigans, 1999; Moseley \& Higgins, 1999).

Besides infrastructure and hardware support, support from administrators and colleagues seemed an important motivating factor for teachers to make the effort to integrate ICT into their lessons (Manternach-Wigans, 1999; Moseley \& Higgins, 1999). Research has shown that teachers needed organisational support, such as leaderdriven and project-oriented, with a common vision shared by the school to motivate them to integrate ICT in the curriculum (Martin, 2000; Yee, 2000). More studies point to the fact that administrative support and principal leadership are key factors for successful integration of ICT in schools (Anderson \& Dexter, 2005; Ely, 1999; Gibson, 2001; Leithwood \& Riehl, 2003; McGarr \& Kearney, 2009; OTA, 1995). Other studies have cited multiple levels of leadership such as principal, administrative leadership and technology leadership as influencing factors upon successful technology integration (Anderson \& Dexter, 2005; Shuldman, 2004). The distributed leadership aspect will assist the principal to handle the demands by sharing responsibilities with middle managers while embarking on ICT integration, and to ensure that effective ICT integration takes place, schools will have to become learning organisations supporting continuous learning (Senge et al., 2000).

An important factor that also encouraged teachers to integrate ICT effectively in the classroom was professional development. Teachers were seen as rooted in the traditional instructional form and hence they were not making the necessary effort to integrate ICT to create innovative learning experiences for their students (Demetriadis et al., 2003; Jules Van Belle \& Soetaert, 2001). Results of some studies showed that teachers were not making effective use of ICT in their lessons (OECD, 2001; Pedretti, Mayer-Smith \& Woodrow, 1999a; Zhao \& Cziko, 2001). Some reasons for the 
dissatisfying results of ICT integration could be attributed to teachers' attitude towards computer use (Demetriadis et al., 2003) as well as improper instructional reforms based on improper pedagogical beliefs (Selwyn, Dawes \& Mercer, 2001). Teachers need knowledge of appropriate ICT integration strategies and ICT skills to effectively integrate ICT into their lessons and optimise the benefits for their students' learning (Pedretti, Mayer-Smith \& Woodrow, 1999b). Teachers' professional development has to focus on both ICT skills training as well as appropriate ICT integration strategies in the curriculum (Divaharan \& Koh, 2010). Research studies have shown that effective use of computers is dependent on the teachers' ICT skills as well as their intentions towards ICT use (Albalat \& Tarrago, 1995; Braak, 2001; Chu, 2000; Hodgson, 1995; Vanderlinde, Braak \& Hermans, 2009; Venezky, 2004). Relevant professional development can take the form of observing colleagues, learning from each other, observation of each others' ICT-integrated lessons, as well as the provision of opportunities for teachers to share and collaborate with each other (Blase \& Blase, 1999; Flanagan \& Jacobsen, 2003; Jacobsen, 2001, 2002; Prain \& Hand, 2003).

Recent studies have proposed that in order for schools to undergo transformation and integrate educational innovations effectively, they needed to function as 'learning organisations' (Beyerbach, Walsh \& Vannatta, 2001; Demetriadis et al., 2003; Fauske \& Raybould, 2005; Hayes, Christie, Mills \& Lingard, 2004; Voulalas \& Sharpe, 2005). When schools function as learning organisations, there are changes in the administrative structures that make decision making flexible (Fullan, 1993). Avenues are created to increase involvement by the teachers in the schools in decision making processes and translating ideas into action (Engel, 1990; Hayes, 2007). In such an organisation, there is a strong likelihood that teacher learning complements student learning and this might lead to the teachers meeting the expectations of integrating ICT to engage students in the learning process.

In summary, it can be deduced from the findings presented from the literature review that there are some key factors that influence teachers' intention of ICT use. The factors identified are availability of time, access, shared vision, relevant professional development, multi-faceted leadership, and functioning as a learning organisation. The context for this research study is a secondary school and the study will attempt to relate some of the findings from literature to the data collected from the secondary schools.

\section{Activity theory as a framework in educational research}

Activity theory is a framework that enables the study of different forms of human praxis as developmental processes, with both individual and social levels interlinked at the same time (Kuutti, 1996). It is a framework that focuses on the interaction of human activity and consciousness within its relevant environmental context. Activity theory places emphasis on both the historical development of ideas as well as the active and constructive role of humans, which stems from the classical German philosophy of Kant and Hegel (Kuutti, 1996). This philosophy provides the foundation for the cultural-historical psychology by Leont'ev in 1932, Luria in 1932 and Vygotsky in 1929 and 1960 (Cole \& Engestrom, 1997). Activity theory was adopted for this study because it provides a useful lens to study the interactions that take place amongst the various participants, and serves as a good framework to map the interaction of the factors that play an integral part in the origin of the activity. Context is an entire activity system that integrates the participants, tools, communities as a whole (Barab, 
Barnett, Yamgata-Lynch, Squire \& Keating, 2002; Engestrom, 1993; Joyes, 2008). Studying context means "finding oneself in the thick of particular situations with particular individuals" (Nardi, 1997). The contradictions that occur in activity systems help to understand the 'breakdown' in relationships (Demiraslan \& Usluel, 2008; Murphy \& Rodriquez-Manzanares, 2008). Analysis of contradictions reveal why outcomes were not achieved. Where possible, in some instances, the activity system may be transformed in order to achieve the outcomes.

\section{Proposed multi-level activity systems approach}

In this study, a multi-level activity system approach has been proposed to frame the study and to analyse the data collected. These are the classroom, department, and school activity systems.

Figure 1 shows the classroom activity system. Any activity system can be divided further into sub-systems (Jonassen, 2000; Jonassen \& Rohrer-Murphy, 1999) for ease of analysis of relationships. The consumption sub-system (in Figure 1) represents the relationship between the students and the teacher as well as the relationship among students. This sub-system captures the interaction and collaboration that takes place in the classroom among students and teacher to bring about the learning outcome in an ICT-integrated lesson. In the distribution sub-system, the division of labour among the teacher and students reveals the various roles played by the participants during the ICT-integrated lesson. Finally, the exchange sub-system provides an insight into the rules that mediates the relationship between the teacher and students as well as amongst students.

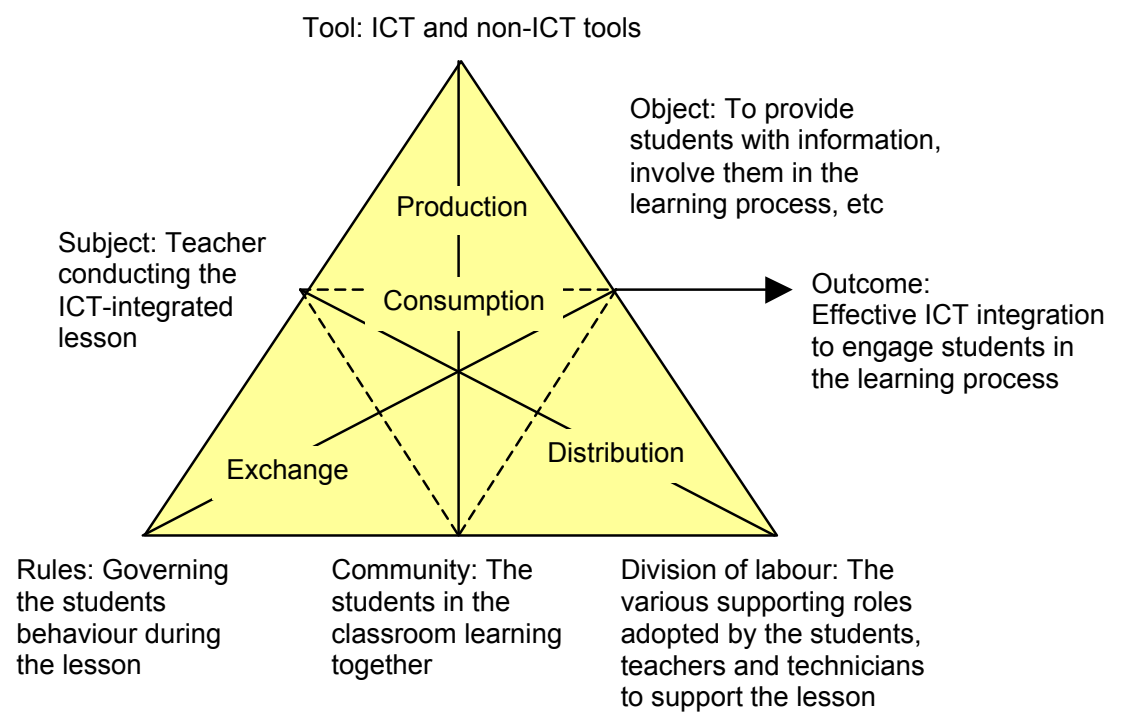

Figure 1: Classroom activity system

The second level of data analysis is the department activity system as seen in Figure 2. The analysis of the production sub-system ascertains the possible tools that mediate the teachers' choice of ICT use. In the consumption sub-system, the relationship among 
the teachers in the instructional program (IP) departments can be analysed. In the distribution sub-system, the division of labour among the teachers in the department can be explored and finally in the exchange sub-system, the focus of the analysis is on any rules in the IP departments that mediate the interaction among the teachers.

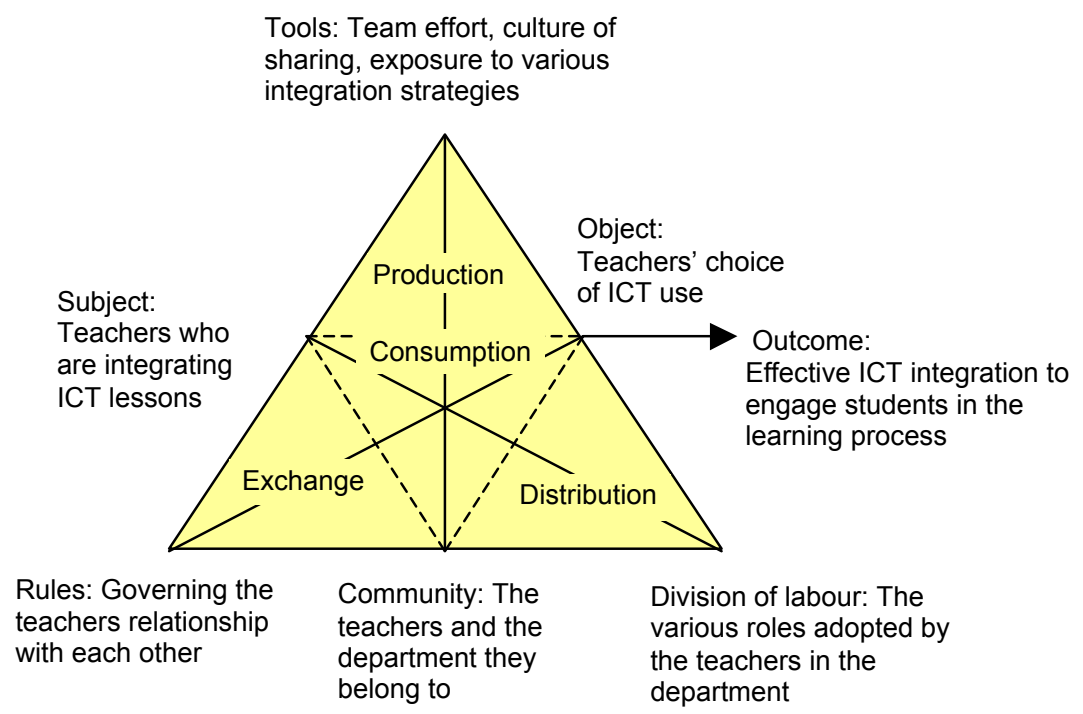

Figure 2: Department activity system

The final level of analysis is the school activity system as reflected in Figure 3. In this activity system, the production sub-system analysis ascertains the possible tools that mediated the teachers' choice of ICT use. In the consumption sub-system, the relationship among the various stakeholders in the school can be analysed to deduce the impact on the production sub-system. The various stakeholders are the teachers, IP/HODs, HOD/ICT and the principal. In the distribution sub-system, the division of labour among the various participants, such as the teachers, HOD/ICT, IP/HODs and the principal can be examined. The exchange sub-system analysis reveals if there were any rules that mediated the interaction among the participants.

Within case analysis of the activity systems at the three levels provides a good grounding for the relationship among the various factors within each school. A cross case analysis reveals similar factors in all the three schools that had an effect on the teachers' choice of ICT. Factors that were unique to each school will be also presented. This cross case analysis and the reporting of the findings provides the researcher with the opportunity to make modest generalisation where feasible (Creswell, 2005).

\section{Research methods}

Multiple case study research is helpful for answering 'how' questions, which are more explanatory, especially when the researcher had minimum effect on the events, and the focus is on a contemporary phenomenon within a real-life secondary school context (Yin, 2003). The events leading to the choice of the type of ICT use can only be understood in the context within which it is occurring (Gillham, 2000; Yin, 2003). 


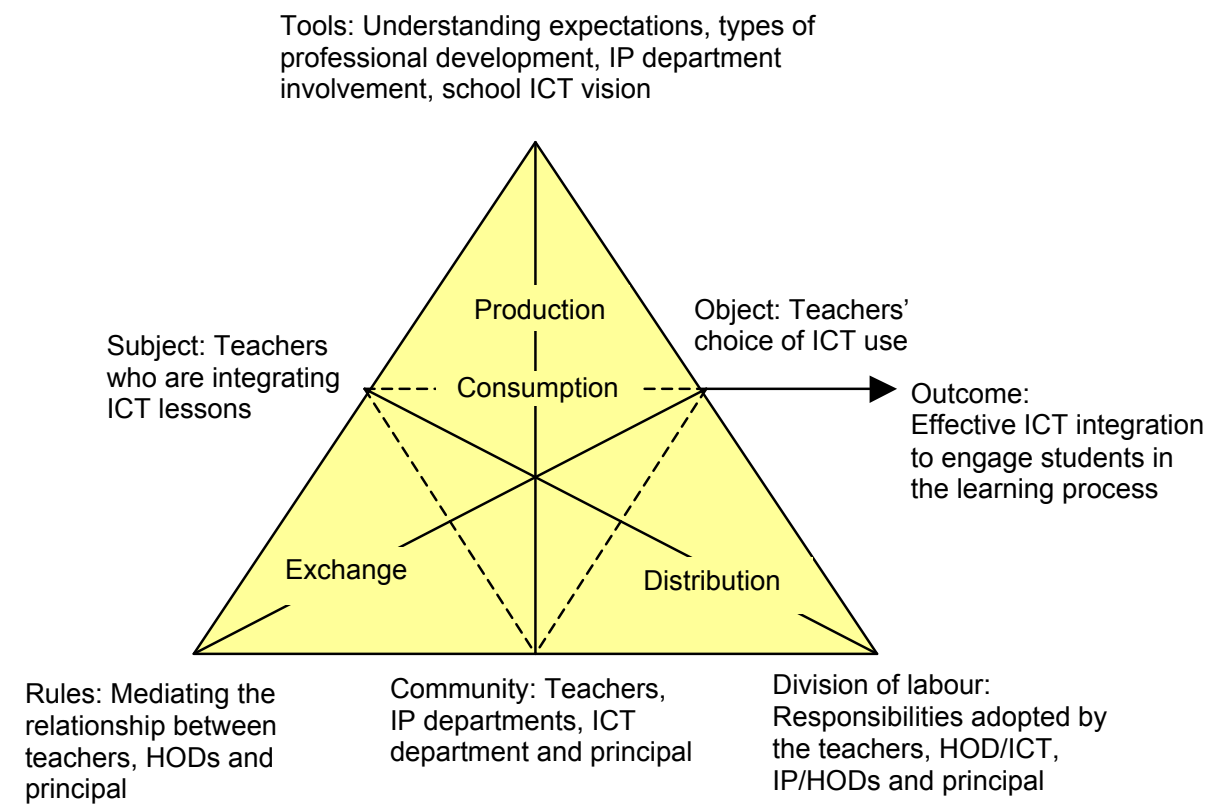

Figure 3: School activity system

The three schools were chosen based on their school types: independent, autonomous and government schools, the three main school types in the Singapore secondary school education system. This intentional selection of the different school types was to provide a basis for comparison of the types of school organisation structure and to explore possible reasons as to whether the different school types might have an impact on the socio-cultural factors influencing the teachers' choice of ICT use in their lessons. All the schools had sufficient hardware and infrastructure provisions for the teachers and students so that ICT integrated lessons can be conducted. The teachers had all undergone basic ICT skills training sessions in the use of MS Word, MS Power Point and Internet and the teachers were conducting ICT lessons on a regular basis, i.e. at least three ICT lessons were conducted per week in the school.

\section{The cases}

\section{School A}

School A is an independent school. The school enjoyed autonomy in setting its own scale of fees, admission criteria for students, implementation of programs and innovations. The school's Board of Governors determined the organisational structure of the school. The school had 130 teaching staff and about 40 support staff or administrative staff.

Organisation structure of the school

Figure 4 shows that at the helm of the school organisation is the Board of Governors. The Board of Governors had the liberty to hire and dismiss any staff in the school, they also decided on the implementation of educational innovations in the school. The Head of Department for ICT (HOD/ICT) and the ICT department are under the direct 
charge of the Second Deputy Head Master who reported to the Head Master of the school. The ICT department organisation structure is illustrated in Figure 5.

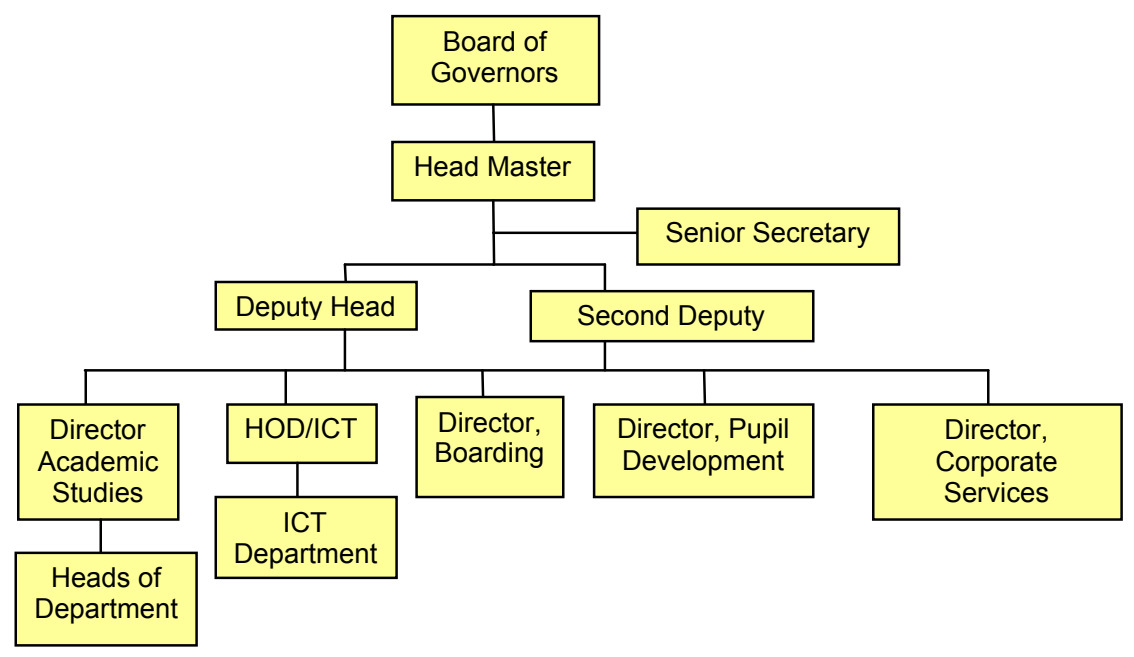

Figure 4: Organisation structure of School A

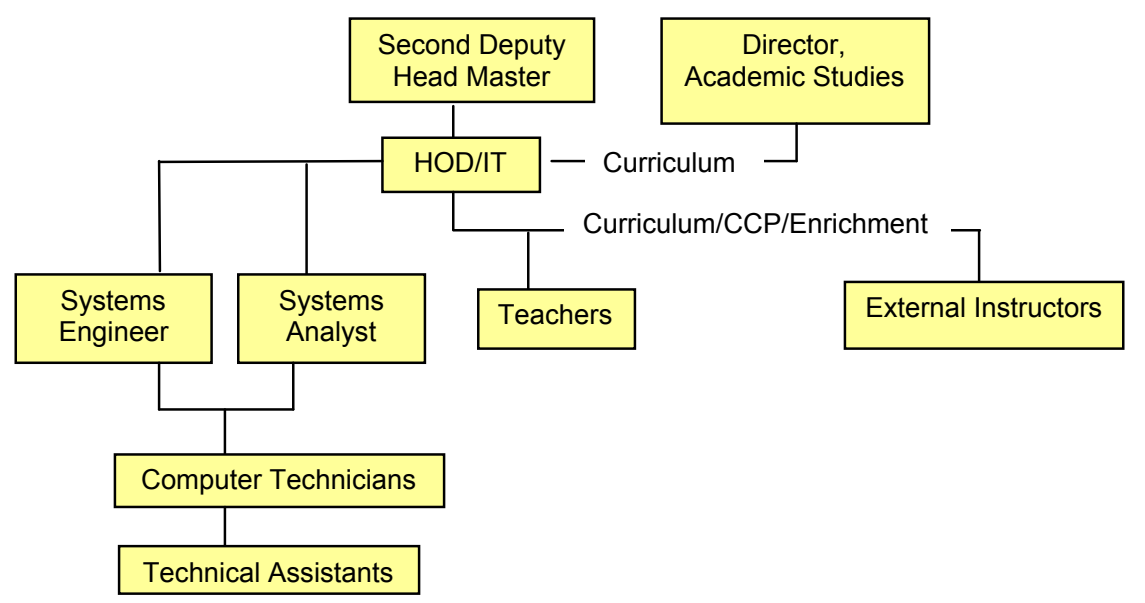

Figure 5: ICT Department organisation structure of School A

HOD/ICT received information and decisions on matters pertaining to curriculum from the Director, Academic Studies. HOD/ICT worked on curriculum related matters and enrichment matters together with two teacher representatives who were nominated based on their interest in the area of ICT.

The hardware and technical matters came under the charge of the Systems Engineer and the Systems Analyst whom the school had hired independent of the provisions made by the Ministry of Education, Singapore. In addition, the ICT department had additional support for hardware maintenance by two computer technicians who 
supervised four technical assistants, who provided assistance to the teachers. The ICT department submitted their proposal to an ICT steering committee (as can be seen in Figure 6) for approval, who then suggested modifications or alternatives where required to the ICT department.

The ICT steering committee set the ICT policy and direction for the school. Decisions about the adoption of educational programs as well as purchase of resources and funding were decided by the ICT steering committee.

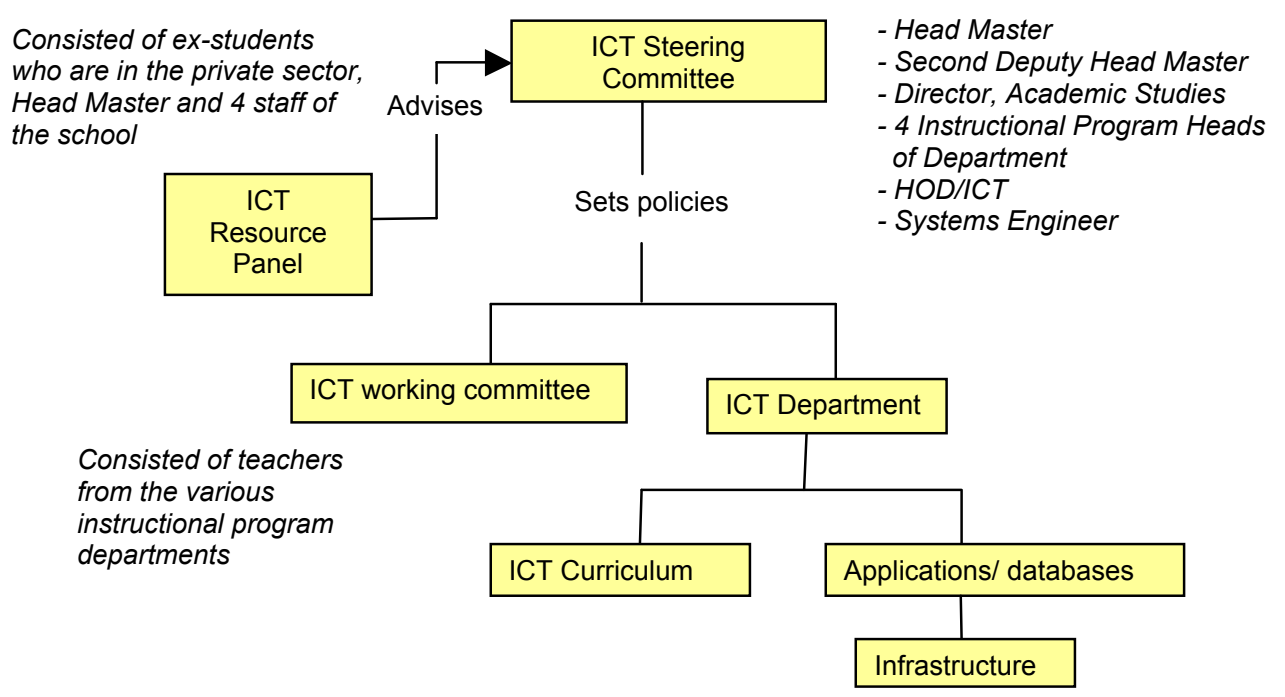

Figure 6: ICT Steering Committee of School A

Leadership

The principal had been with the school for three years. The principal did not receive any formal training in ICT skills or ICT integration and has no prior experience in implementing ICT or integrating ICT in a subject. Hence, he worked closely with the ICT department and the ICT steering committee for advice and support in making decisions for the school. Due to his lack of ICT skills and experience in the area of integrating ICT, he preferred that the HOD/ICT initiated programs for his and the committee's perusal and monitored the implementation of ICT in the school as well as integration in the subjects.

Support and professional development

The teachers requested for technical support in times of trouble. The technicians were on call to assist the teachers as well as to set up the systems in the labs to the configuration requested by the teachers to support their lessons. In addition to having the technicians as support staff, the students in every class were trained to handle minor technical problems. They assisted by setting up the teacher's computer in the classroom. If the teachers required any ICT skills training, they informed the ICT department through their IP Heads for the necessary arrangements to be made. 


\section{School B}

School B is an autonomous school but functions under the broad educational framework set by MOE, Singapore. The main difference between an autonomous school and a government school was that the autonomous school was given additional funds by MOE so that they can concentrate on providing additional enrichment activities for their students to provide them with holistic education. The second difference is that although autonomous schools charged the same school fees as a government schools, they were allowed to exercise the option of charging additional miscellaneous fees to help support the additional programs it offered its students. Unlike an independent school, the autonomous school was not allowed to decide on the criteria for admission of students into the school.

Organisation structure of the school

At the advisory level, the school had an Advisory Committee consisting of a Chairman (who was an ex-student of the school and held a reputable position), a Vice-Chairman (who held a CEO position), a Secretary who was the school's principal, Assistant Secretary who was the school's vice-principal and a Treasurer. They had a few committee members to complete the committee. The Advisory Committee met with regard to school educational goals and directions, reviewed progress of the school and planned with regard to the finances of the school.

From Figure 7, the school's organisation structure shows that the position of the ICT Department in School B was at the same level as the IP departments. They were all under the charge of the principal and the Vice-principal. The ICT Department was labelled as 'Information Technology and Media Resource Library'. The structure of the ICT Department was similar to the other IP Departments in that the HOD/ICT was assisted by a Subject Head. The difference in structure stems from the fact that the ICT department had IP Heads as part of the department or represented by teachers for that subject area.

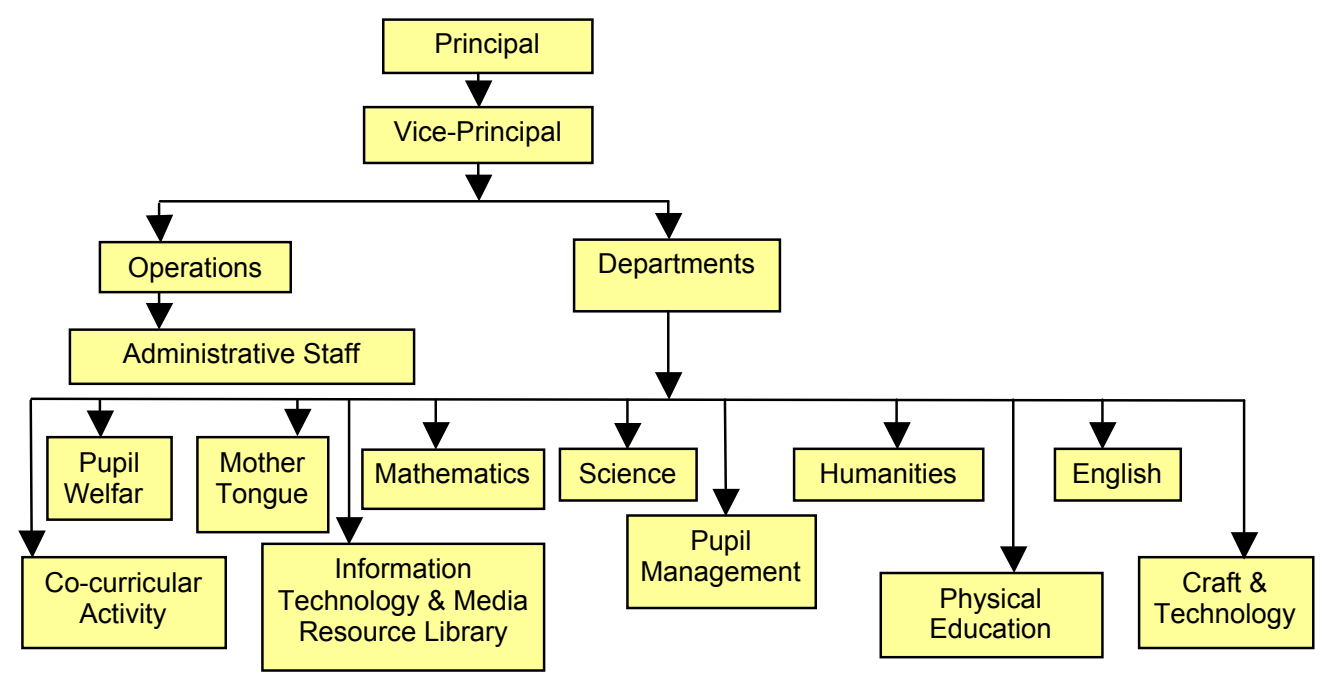

Figure 7: Organisation structure of School B 
The ICT Department organisation structure

The ICT Department organisation structure is presented in Figure 8. The HOD/ICT reported directly to the principal. The principal was directly involved in the running of the Department and was involved in discussion with regard to strategies to adopt for implementing ICT in the school. The implementation of ICT in the school and monitoring the progress of ICT implementation and receiving feedback from the teachers were the ICT Department's responsibility.

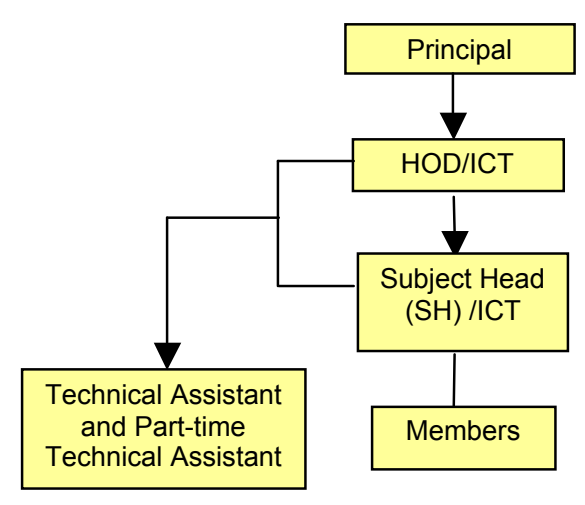

Figure 8: ICT Department organisation structure of School B

HOD/ICT worked together with the Subject Head (SH/ICT) and members of the Department. The members were teachers who were keen in the area of ICT and worked with the committee to formulate direction and policies for the school. HOD/ICT and the SH/ICT have a Technical Assistant and a part-time Technical Assistant to help them to maintain hardware and infrastructure related problems. The Technical Assistant was appointed to the school under the provisions made by MOE as part of the MPITE. The school hired a part-time Technical Assistant based on their need for extra technical support to maintain their hardware and infrastructure.

The ICT Department did not operate independently. They received information and decisions regarding policies from the ICT Steering Committee (as reflected in Figure 9). This committee consisted of representatives from all the Instructional Program (IP) departments. They were usually the IP/HODs but in some situations, a teacher who was ICT savvy represented the department rather than the IP/HOD, especially if the IP/HOD was not very competent or confident in the use of ICT. This enabled the department representative to assist the ICT department to make informed decisions. These IP representatives were responsible for ensuring that two-way feedback took place. The school's ICT goal was to have seamless integration of ICT through changes in pedagogy as well as to implement e-learning to provide students with independent learning skills. The principal's approach was to involve the IP heads, thereby making them responsible for ICT integration in their subject area. This modus operandi empowered them to make sure their department teachers were progressing from one level of ICT integration to the next through constant monitoring processes. Thus, the principal aimed to integrate ICT into the curriculum and hoped to bring about seamless integration vis-à-vis a whole school approach. 


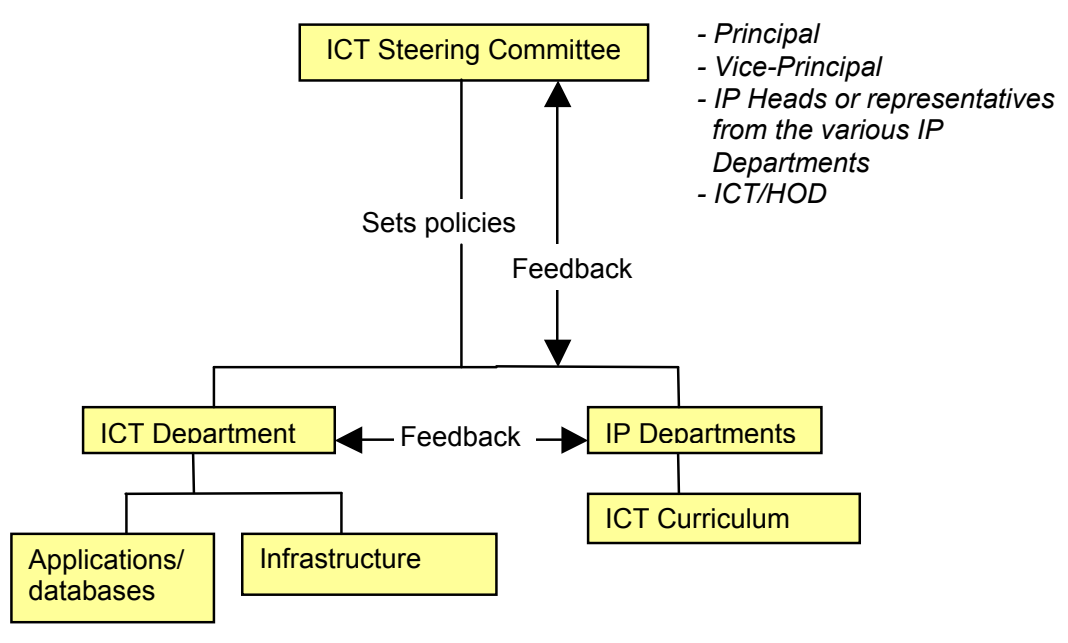

Figure 9: The ICT Steering Committee of School B.

\section{Leadership}

The principal was the eleventh principal of the school. She had been with the school for four years. The principal had an Associate Degree from the United States of America in the area of Microcomputer Business Application. The principal has good knowledge of ICT integration skills which was build up through her involvement with the Educational Technology Division (ETD) in MOE, Singapore. In her job scope as an ETD officer, she explored various types of ICT integration in the area of English language and trained teachers in schools to plan and integrate ICT in the various subject areas, especially English Language. Therefore, she had personal experience and knowledge of how to integrate ICT in subject areas as well as the skill of training teachers since she had personally conducted training during her stint with ETD.

The leadership style of the principal in the area of ICT implementation was direct involvement with the teachers. The principal clearly communicated the importance of ICT integration in subject areas and demonstrated it by taking an interest in the type of ICT lessons that the teachers conducted. She monitored the teachers by observing the types of lessons that they conducted and reviewed the lessons together with the teachers and also personally praised them for their efforts. The principal sourced training and guidance for her teachers because she felt the teachers needed exposure to various ICT integration approaches to achieve the goal of the school - that is to enable their students to become independent learners.

The principal modelled ICT integration in the area of English Language which was her forte, thereby, leading by example. The principal also made attempts to involve parents for a more concerted effort to get the students to be more independent learners and to make use of the resources that the teachers had prepared and put up online for their learning benefit.

Being the Chair of the ICT Steering Committee, the principal was aware of the hardware and software resources as well as the preferences of the teachers based on 
the feedback that the Steering Committee received. The principal monitored the ICT Department and in the process she planned the finances together with the HOD/ICT to ensure that they managed the funds to maximise the use of the funds for the benefit of the teachers in the area of ICT.

\section{Support and professional development}

Training sessions conducted for teachers were based on the needs of the teachers rather than a mass training session for the staff in the school as compared to School A. These needs were communicated to the IP/HODs who then proposed the training session for the all the staff in the department or for a group of teachers teaching a certain level and who needed to use the software. This was brought up for discussion at the Steering Committee level to approve the training. The ICT Department then followed up with the necessary arrangements for the training to be conducted.

The school's objective was to enable the teachers to seamlessly integrate ICT in their lessons and to optimise the potential of ICT as a learning tool. In order for this to materialise, the principal made the effort to put the teachers in contact with ETD trainers who assisted the teachers during training sessions to plan and review their ICT integration strategies to utilise ICT to engage students in the learning process.

\section{School C}

School C was a government school. As a government school, the school adhered to the guidelines set by the Ministry of Education (MOE), Singapore. The school charged the same school fees as other government schools. The school received its posting of students from the Ministry after the PSLE results. The school was allowed to offer a range of educational programs for the students provided these can be managed within the school fees and the miscellaneous fees that the students were paying.

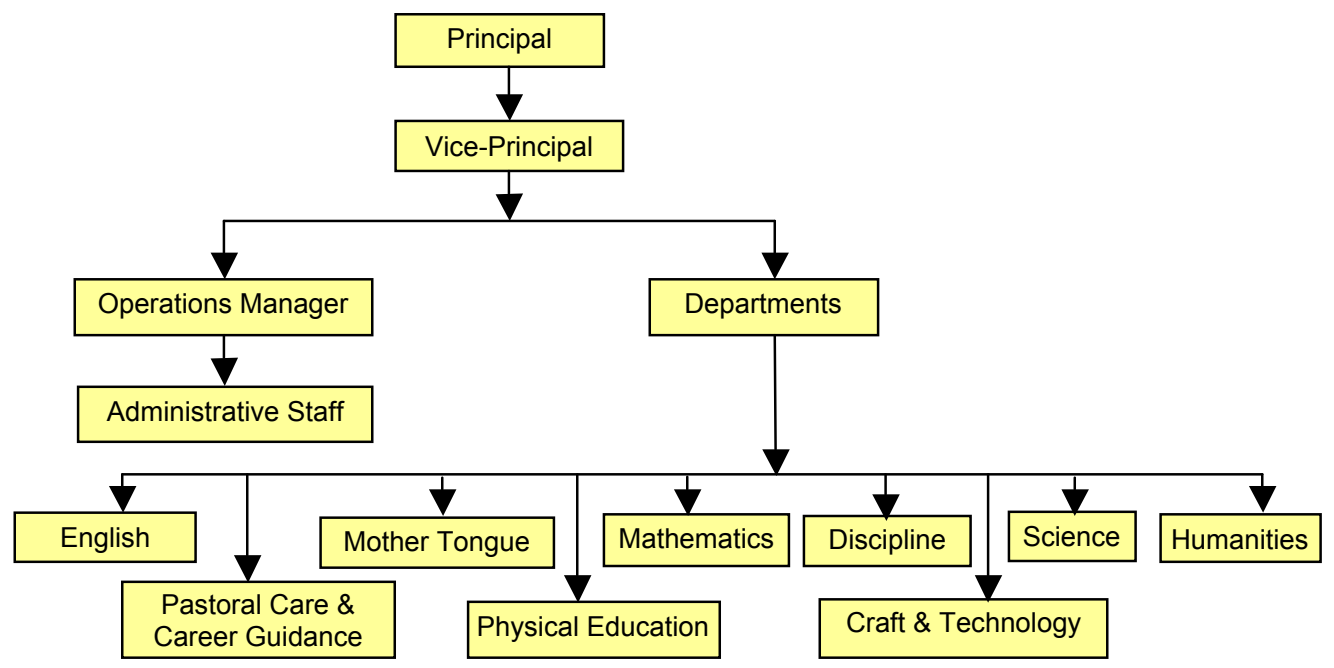

Figure 10: Organisation structure of School C 
Organisation structure of the school

At the advisory level, the school had a School Advisory Committee, which held meetings with regard to matters pertaining to the school's educational goals and directions, reviewed the progress made by the school and matters pertaining to the finances of the school. This is practised by all government schools in Singapore.

At the operational level, the principal headed the school, assisted by the vice-principal. The Operations Manager took care of the administrative matters in the school, while the IP Heads took charge of each subject area. They each had a Subject Head (SH) to assist them. In School C, there was no formal ICT department and the HOD/ICT worked on her own together with the Technical Assistant to oversee the implementation of ICT in the school. This is presented in Figure 10.

The ICT Department organisation structure

From Figure 11, it can be seen that the ICT 'Department' was made up of only two people in the school. One was the HOD/ICT and the other, the Technical Assistant who was hired as part of the provisions made by MOE, Singapore. The HOD/ICT planned the ICT implementation approach for the school and discussed the plan with the principal. While the HOD/ICT looked into hardware provisions for the school and the infrastructure set up, the Technical Assistant ensured that the computers were maintained in the school.

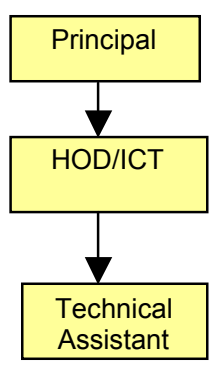

Figure 11: ICT Department Organisation Structure of School C

The norm for acquiring ICT resources was through ad hoc means, based on the needs of the IP departments. If the IP/HODs or the teachers came across any resource that they felt was beneficial, they approached the ICT/HOD and informed her so that she made the necessary purchase for the school. The school did not have any distinct ICT vision, mission or goals to drive the ICT implementation process. The IP/HODs were not formally involved in the ICT implementation process. There was no central thrust for them to get together to contribute. The effort to implement ICT in their subject area came from individual teachers within the departments and the IP/HODs were required to set the lead for their department based on what they felt best suited the needs of the department.

Leadership

It was the principal's fourth year in the school. The principal did not have any professional training as she had not "gone through DEA neither (has she) gone through LDP or LSE" (these are all leadership training programs for principals). The principal's own experience of ICT integration stemmed from the time when she herself was a teacher and attempted to integrate ICT into her lessons. The principal's style of 
introducing ICT to her teachers was by encouraging the teachers to use ICT in the area of administrative work. The principal hoped that the teachers' use of ICT in their administrative work would make them more comfortable in the use of ICT. The principal was generally aware of what was happening in the school. The HOD/ICT updated and discussed with the principal about financial matters related to ICT. With regard to integration at the curricular level, the principal expected the IP/HODs and HOD / ICT to take the lead and address the needs of the teachers and put in place the necessary processes at department level for ICT integration to take place.

Support and professional development

The implementation of ICT in the school had been left to the HOD/ICT as well as the IP/HODs. They decided what the department teachers can handle and what type of integration they wanted to adopt. The selection of ICT integration strategies varied as each department decided on the amount of ICT integration and the types of resources they wanted to integrate in their subject area with no over-arching goal or vision from the school. ICT training sessions for teachers were conducted based on their needs. Training sessions for the students were again conducted on a just in time basis.

\section{Research methods and data analysis}

Figure 12 represents the data collection and analysis process. The data collection comprised of ICT integrated lesson observations, formal interviews with teachers, HOD/ICT and principal, focused group interviews with students and relevant documents collected as and when possible and available.

This multi-method approach of data collection within a case study approach helped in the process of triangulation (Gillham, 2000; Yin, 2003). In triangulation, the multiple sources of evidence or data collected are aimed at corroborating the same fact or phenomenon. Utilising data in such a corroboratory manner implies that the findings or conclusions drawn from these case studies are likely to be more convincing and accurate (Maykut \& Morehouse, 2000; Yin, 2003). The data collection method was framed by the three levels of activity systems as shown in Figures 1, 2 and 3. Hence, the various stakeholders were interviewed (Figure 12). In addition, for triangulation purposes, lesson observations were conducted and relevant documents were examined.

Data gathered from the three schools each formed a case study. The data collected by means of multi-method data collection was analysed through the constant comparative method (Glaser \& Strauss, 1967). As explained in the three-levels of activity systems (Figures 1, 2 and 3), the interaction of factors was examined at each activity systems level to understand the factors that supported the outcome of the ICT integrated lessons. After examining the factors at each activity system level, comparison of different activity systems was also conducted to examine the relationship between the three activity systems. Once within case analysis was completed, across case analysis of the activity systems were conducted understand similarities and differences in the interaction of factors in the three schools. Where the outcomes were not achieved, the contradictions in the activity systems and across activity systems were explored to understand why and to suggest improvements. 


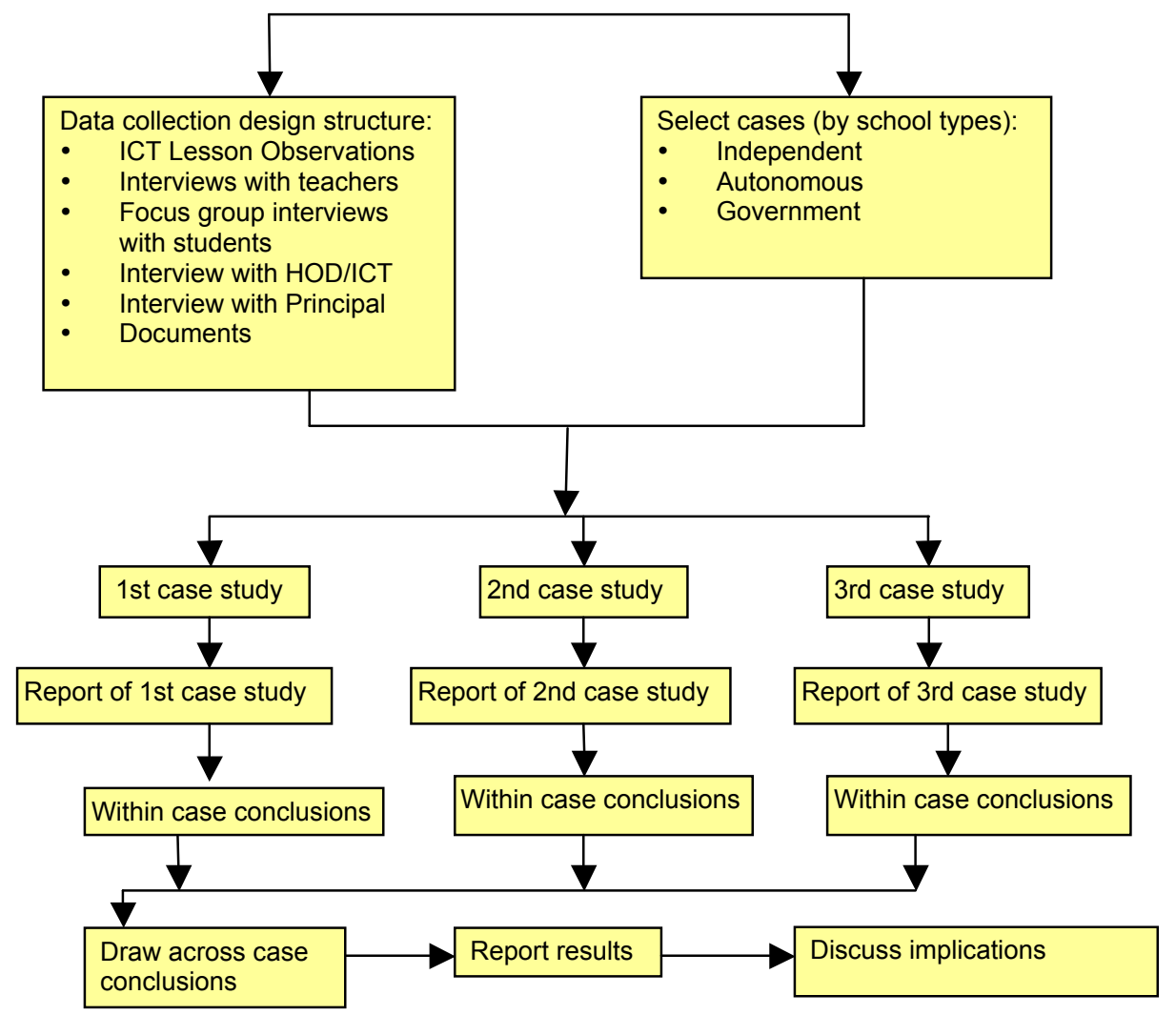

Figure 12: Representation of data collection and analysis process for the study

\section{Key findings and discussion}

The comparison of the three schools revealed that the interaction of factors at the various activity system levels seemed pertinent for schools to be successful in achieving their desired goal.

The findings from data analysis have been summarised in Table 1. It is evident that there existed an environment conducive for ICT integration to take place in School A. The students provided assistance to the teachers and adhered to the proper protocol of computer usage, enabling the teachers to focus on lesson delivery and optimise time for students to learn. The provision of ICT skills training to students enabled the students to be competent users of computers during the lesson. The students also had ample access to computers at home and in school. The students' readiness for ICT lessons might have been a result of the fact that they possessed the ability acquired through the ICT skills training sessions. In addition, the students' positive attitude of independent learning of ICT skills probably assisted in the integration of ICT lessons to enhance their learning. The school activity system provided support to the classroom activity system. There was ample technical support for the teachers if any technical problems should arise, providing assurance to teachers. 
Table 1: Within and across schools analysis

\begin{tabular}{|c|c|c|c|c|c|}
\hline \multirow{2}{*}{\multicolumn{3}{|c|}{ Factors }} & \multicolumn{3}{|c|}{ School } \\
\hline & & & A & B & $\mathrm{C}$ \\
\hline \multirow{3}{*}{$\begin{array}{l}\text { Classroom } \\
\text { activity } \\
\text { system }\end{array}$} & \multicolumn{2}{|c|}{ Division of labour (trained student ICT representatives) } & $\checkmark$ & $\checkmark$ & \\
\hline & \multicolumn{2}{|c|}{ Rules (seating arrangement, protocol for ICT usage) } & $\checkmark$ & $\checkmark$ & \\
\hline & \multicolumn{2}{|c|}{$\begin{array}{l}\text { Community and subject (students are competent and comfortable using } \\
\text { ICT) }\end{array}$} & $\checkmark$ & $\checkmark$ & \\
\hline \multirow{10}{*}{\begin{tabular}{|l} 
Depart- \\
ment \\
activity \\
system
\end{tabular}} & \multirow[t]{2}{*}{ Rules } & Minimum requirements for ICT integrated lessons & $\checkmark$ & $\checkmark$ & $\checkmark$ \\
\hline & & Understanding of types of lessons & & $\checkmark$ & \\
\hline & \multirow{2}{*}{$\begin{array}{l}\text { Division of } \\
\text { labour }\end{array}$} & Online platform to share resources & $\checkmark$ & $\checkmark$ & \\
\hline & & Formal time to share within department & & $\checkmark$ & \\
\hline & \multirow{4}{*}{$\begin{array}{l}\text { Commun- } \\
\text { ity and } \\
\text { subject }\end{array}$} & Formal sharing sessions within all departments & & $\checkmark$ & \\
\hline & & Formal sharing sessions in some departments & $\checkmark$ & & \\
\hline & & Informal sharing sessions within all departments & & $\checkmark$ & \\
\hline & & Informal sharing sessions in some departments & $\checkmark$ & & $\checkmark$ \\
\hline & \multirow{2}{*}{\multicolumn{2}{|c|}{$\begin{array}{l}\text { Principal involved in encouraging teachers to make the transition } \\
\text { HOD/ICT involved in encouraging teachers to make the transition }\end{array}$}} & & $\checkmark$ & \\
\hline & & & $\checkmark$ & $\checkmark$ & $\checkmark$ \\
\hline \multirow{15}{*}{\begin{tabular}{|l} 
School \\
activity \\
system
\end{tabular}} & \multirow[t]{4}{*}{ Rules } & Clear ICT goals & $\checkmark$ & $\checkmark$ & \\
\hline & & Articulated to the teachers & & $\checkmark$ & \\
\hline & & Clear guidelines for translating into practice & & $\checkmark$ & \\
\hline & & Clear understanding of the type of ICT use in the lessons & & $\checkmark$ & \\
\hline & \multirow{7}{*}{$\begin{array}{l}\text { Division of } \\
\text { labour }\end{array}$} & Principal leadership - active involvement & & $\checkmark$ & \\
\hline & & Principal leadership - perceived as involved by teachers & & $\checkmark$ & \\
\hline & & Principal leadership - perceived as being supportive & $\checkmark$ & $\checkmark$ & $\checkmark$ \\
\hline & & HOD/ICT leadership - experience in ICT related areas & $\checkmark$ & $\checkmark$ & $\checkmark$ \\
\hline & & $\begin{array}{l}\text { HOD/ICT leadership - in charge of ICT integration in } \\
\text { school }\end{array}$ & $\checkmark$ & $\checkmark$ & $\checkmark$ \\
\hline & & HOD/IP leadership - all are actively involved & & $\checkmark$ & \\
\hline & & HOD/IP leadership - some are actively involved & $\checkmark$ & & $\checkmark$ \\
\hline & \multirow[t]{2}{*}{$\begin{array}{l}\text { Subject and } \\
\text { community }\end{array}$} & $\begin{array}{l}\text { Professional development - teachers received ICT skills } \\
\text { training }\end{array}$ & $\checkmark$ & $\checkmark$ & $\checkmark$ \\
\hline & & $\begin{array}{l}\text { Teachers received subject related training for ICT } \\
\text { integration }\end{array}$ & & $\checkmark$ & \\
\hline & \multirow{2}{*}{\multicolumn{2}{|c|}{$\begin{array}{l}\text { Teachers had time to explore and plan for ICT integration } \\
\text { Teachers wanted more time to explore resources and plan for ICT } \\
\text { integration }\end{array}$}} & & $\checkmark$ & \\
\hline & & & $\checkmark$ & $\checkmark$ & $\checkmark$ \\
\hline
\end{tabular}

At the school activity system level, School A had clear ICT goals to develop students to be independent learners. Internal contradiction within the school activity system arose due to the teachers' perception of the lack of visible involvement by the principal of the school. Hence, the teachers did not see the importance of ICT integration in the curriculum nor were they aware of the expectations of the school since there was no modelling or precedents for them to follow.

Additional contradictions surfaced within the school activity system. The IP/HODs were not significantly involved in the ICT implementation process. This was possibly because there was no perceptible effort to empower the IP/HODs to lead their departments in integrating ICT in the curriculum. This resulted in infrequent and informal sharing sessions that sprouted on an ad hoc basis for some departments while in others there was only level sharing. This lack of concerted effort for sharing of ICT strategies and resources at the department level was possibly exacerbated by the external contradiction from the school activity system, with lack of direction and involvement of the IP/HODS. Consequently, this might have affected the department activity system leading to a lack of strong culture of sharing within the department. On 
the contrary, the HOD/ICT was more actively involved in the integration process because it was an ICT implementation process. It thus seemed that the integration process was more technology driven rather than curriculum focused.

In School A, the supporting factors in the department activity system such as technical support and uniform learning management system provided added support for ICT integration at the classroom activity system level. At the classroom activity system level, there existed an environment for ICT integration with ICT-enabled classrooms and computer labs, and students' readiness for ICT-integrated lessons. Internal contradictions at the department activity system revealed lack of strong culture of sharing and inadequate communication of expectations. External contradictions arising from the school activity system as a result of lack of IP/HODs and principal's visible involvement impacted the department activity system, constraining the culture of sharing. This might have also have been a cause for the department activity system's external contradiction to the school activity system where provision of relevant professional development was affected. Factors such as lack of visible leadership involvement as perceived by the teachers, inadequate strong culture of sharing within the department and lack of relevant professional development seemed to be strong factors determining the effective integration of ICT in the classroom.

As for School B, at the classroom activity system level, the interaction of the factors revealed an environment conducive for ICT integration. The classrooms and computer labs had adequate infrastructure support. The teachers had assistance from trained student ICT representatives. Since the students adhered to the required protocol of computer usage, the teachers did not face any major management issues. The ICT competency and comfort level of the students indicated their readiness for ICTintegrated lessons. The interaction of the factors at the classroom activity level revealed the preparedness of students and teachers for ICT integrated lessons.

The interaction of the factors at the school activity system revealed possible strong impact on the effectiveness of ICT integration. School B had clearly articulated their ICT goals to the teachers through the IP departments. The teachers were aware of the school's expectations of ICT integration to engage students in the learning process. Clear articulation of the expectations at the school activity system had a positive impact on the department activity system. The department sharing sessions were aimed at providing teachers with wider exposure to relevant ICT integration strategies and which encouraged effective ICT integration. A positive effect of the interaction of the factors at the school activity system was the practice of distributed leadership in the school. The principal set the tone for the overall ICT integration and adopted a visible role in ICT integration within the curriculum through modelling expectations. The translation of the goal of ICT integration was shared by the IP/HODs and HOD/ICT. The HOD/ICT was in charge of providing the relevant infrastructure support. The IP/HODs were empowered to lead their department using the ICT goals as guiding principle to achieve ICT integration within curriculum. The IP/HODs thus took lead in charting the direction for their departments to achieve the school's ICT target. This had a positive effect at the department activity system level where the sharing sessions and schemes of work reflected ICT integration strategies and ICT resources. The department sharing sessions possibly created a team effort where the teachers were exposed to wider integration strategies as well as ICT resources. This interaction of factors at the department activity system level had a positive effect on the school activity system because the teachers did not complain about lack of resources or lack of time. 
The data analysis for School $\mathrm{C}$ exhibited internal contradictions reflecting a lack of readiness of the school to integrate ICT in their curriculum. The school lacked hardware and network infrastructure. The school also did not have a common network platform for the students and teachers to utilise. The students lacked ICT exposure relevant ICT skills training. Therefore, they seemed less competent in handling ICT integrated lessons. When conducting ICT integrated lessons, the teachers sometimes had an extra responsibility to conduct just in time skills training for the students. Another internal contradiction was that the school did not have a pool of trained ICT student representatives to provide assistance to the teachers. The interaction of the factors in the classroom activity system suggested an environment not supporting ICT integration. In addition, the classroom activity system was affected by the external contradiction exhibited by the department activity system. There was lack of technical support and this led to teachers' apprehension for conducting ICT integrated lessons.

The school activity system exhibited internal contradictions. The school lacked an overall guiding ICT goal and implementation plan. This lack of direction together with a lack of formal committee for ICT implementation and a non-existing ICT department were an indication that School C did not have clear directions for their ICT integration process. This internal contradiction within the school activity system affected the department activity system revealing a lack of evident culture of sharing within the departments. The IP/HODs were expected to take initiative to lead their departments. With lack of direction, the departments were progressing at various rates.

At the school activity system level, the principal did not have a clear ICT implementation plan and did not make a concerted effort for a whole school approach to ICT integration. The teachers, however, noticed that the principal provided support by encouraging ICT use to improve administrative efficiency. The contradictions at the school activity system might have affected the department activity system where there was no official committee created to guide the ICT implementation process for the school. The IP/HODs were not formally involved or provided with guidance. The HOD / ICT functioned as a sole member of the 'ICT Department' and was assisted by the technical assistant. This lack of involvement of the Heads might have created the impression that ICT integration is not a necessity.

The internal contradiction in the department activity system caused by a lack of culture of sharing became an external contradiction affecting the school activity system. Since the teachers lacked exposure to ICT integration strategies and resources, this translated into lack of resources and time constraint to source for resources. This was exacerbated by internal contradiction at the school activity system level where the teachers were not provided with relevant professional development.

From the analysis of the three school case studies and the three levels of activity systems within each school case study, inferences of a supportive socio-cultural context can be derived. Schools need to function as learning organisations to be adaptable to changes, especially rapid changes brought about by technology integration in curriculum. To be successful learning organisations, schools need a curriculum focused, overarching ICT goal to provide clear direction to the key players - teachers, HOD/ICT and IP/HODs in the school. The management approach to ICT integration in the school should be through distributed leadership. While the principal sets the tone for the school vis-à-vis modelling of curriculum focused integration, providing encouragement to teachers and support for the HODs plans, the role of the HOD/ICT would be to ensure the relevant ICT-enabled infrastructure and 
implementation procedures are in place. The role of the IP/HODs is to ensure that there is a strong culture of sharing within the department, so that the teachers can learn from each other and be exposed to a variety of ICT integration strategies and resources aligned to the school's expectations. The IP/HODs also play a vital role in including the teachers in the implementation process through involving them in goal setting at the department level and to decide on the course of action. In addition, the IP/HODs are to work closely with the teachers to ensure relevant professional development was provided to meet teachers' needs.

\section{Limitations of the study}

One of the main assumptions made in the study by adopting the activity theory framework is that actions are intended and purposeful to help the subject to transform the object through interaction and mediation with other components of the activity system to achieve the outcome of the activity. This goal-directed activity is usually driven by a larger context - the school. The assumption made in this study is that the intention of the school is to provide support to the teachers to encourage effective ICT integration. Reflecting on the three schools, Schools A and B clearly articulated that their intention of the need for effective ICT integration. School C, however, did not have any clear goal or intention for ICT integration. Another limitation was the lack of accessibility to interview all the IP/HODs and to observe the staff meetings and sharing sessions. This access would have enabled the researcher to ascertain the type of leadership style that was most suited to bring about transition among teachers to integrate ICT in their lessons.

\section{Conclusion}

The findings from this study have useful information for the various stakeholders involved in the ICT integration process. For the principal, it creates an awareness of the important lead that the principal has to role model to the HODs and teachers to translate expectations into actions. The HODs need to be aware of their important role of middle managers who assist in communicating expectations to their teachers and to ensure that the teachers are included as stakeholders in the implementation process. The HODs have to ensure that they create a supportive environment for their teachers to work as a team to learn from each other and to support each other. The teachers and students need to be aware that they have an important part to play in ensuring the successful translation of educational initiatives into classroom practices. The teachers have to be team players willing to learn, share and contribute for the benefit of their peers. School have to function as learning organisations which are able to work as a team and constantly adapt in order to meet the constantly changing educational landscape for the benefit of their students and to optimise the learning opportunities offered to them.

\section{References}

Albalat, J. Q. i. \& Tarrago, F. R. (1995). Interpreting internal school factors on the educational integration of IT. In D. Watson \& D. Tinsley (Eds.), Integrating information technology into education. UK, London: Chapman \& Hall.

Anderson, R. E. \& Dexter, S. (2005). School technology leadership: An empirical investigation of prevalence and effect. Educational Administration Quarterly, 41(1), 49-82. 
Barab, S. A., Barnett, M., Yamgata-Lynch, L., Squire, K. \& Keating, T. (2002). Using activity theory to understand the systemic tensions characterizing a technology-rich introductory astronomy course. Mind, Culture and Activity, 9(2), 76-107.

Beyerbach, B., Walsh, C. \& Vannatta, R. (2001). From teaching technology to using technology to enhance learning: Pre-service teachers' changing perceptions of technology infusion. Journal of Technology and Teacher Education, 9(1), 105-127.

Blase, J. \& Blase, J. (1999). Principals' instructional leadership and teacher development: Teachers' perspectives. Educational Administration Quarterly, 35(3), 349-378.

Braak, J. v. (2001). Individual characteristics influencing teachers' class use of computers. Journal of Educational Computing Research, 25(2), 141-157.

$\mathrm{Chu}, \mathrm{J}$. L. (2000). Assessment of the integration of technology into the curriculum by middle and high school teachers. Unpublished EdD, Pepperdine University.

Cole, M. \& Engestrom, Y. (1997). A cultural-historical approach to distributed cognition. In G. Salomon (Ed.), Distributed cognitions: Psychological and educational considerations. New York: Cambridge University Press.

Creswell, J. W. (2005). Educational research: Planning, conducting and evaluating quantitative and qualitative research. New Jersey: Pearson Prentice Hall.

Cuban, L. (1993). Computers meet classroom: Classroom wins. Teachers College Record, 95, 185-210.

Cuban, L. (2001). Oversold and underused. USA: Harvard University Press.

Dawson, K. \& Heinecke, W. (2004). Conditions, processes and consequences of technology use: A case study. Technology, Pedagogy and Education, 13(1), 2004.

Demetriadis, S., Barbas, A., Molohides, A., Palaigeorgiou, G., Psillos, D., Vlahavas, I., et al. (2003). Cultures in negotiation: Teachers' acceptance/ resistance attitudes considering the infusion of technology into schools. Computers $\mathcal{E}$ Education, 41, 19-37.

Demiraslan, Y. \& Usluel, Y. K. (2008). ICT integration processes in Turkish schools: Using activity theory to study issues and contradictions. Australasian Journal of Educational Technology, 24(4), 458-474. http:/ / www.ascilite.org.au/ajet/ ajet24/demiraslan.html

Dias, L. B. (1999). Integrating technology. Learning \& Leading with Technology, 27(3), 10-21.

Divaharan, S. \& Koh, J. H. L. (2010). Learning as students to become better teachers: Pre-service teachers' IWB learning experience. In M. Thomas \& A. Jones (Eds), Interactive whiteboards: An Australasian perspective. Australasian Journal of Educational Technology, 26(Special issue, 4), 553-570. http:/ / www.ascilite.org.au/ajet/ajet26/divaharan.html

Ely, D. P. (1999). Conditions that facilitate the implementation of educational technology innovations. Educational Technology, November/December, 23-27.

Engel, D. E. (1990). Pittsburgh's teacher-administrator partnership: a new relationship. Educational Leadership, 47(8), 44-45.

Engestrom, Y. (1993). Developmental studies of work as a testbench of activity theory: The case of primary care medical practice. In S. Chaiklin \& J. Lave (Eds.), Understanding practice: Perspectives on activity and context. (pp. 64-103). Cambridge: Cambridge University Press.

Ertmer, P. A. (1999). Addressing first-and second-order barriers to change: Strategies for technology integration. Educational Technology Research \& Development, 47(4), 47-61. 
Fauske, J. R. \& Raybould, R. (2005). Organisational learning theory in schools. Journal of Educational Administration, 43(1), 22-40.

Flanagan, L. \& Jacobsen, M. (2003). Technology leadership for the twenty-first century principal. Journal of Educational Administration, 41(2), 124-142.

Fullan, M. (1993). Changing forces: Probing the depths of educational reform. London: Falmer Press.

Gibson, I. W. (2001). The role of school administrators in the process of effectively integrating educational technology into school learning environments: New research from the mid-west. In J. Price et al. (Eds.), Proceedings of Society for Information Technology \& Teacher Education International Conference 2001 (pp. 502-506). Chesapeake, VA: AACE.

Gillham, B. (2000). Case study research methods. London: Continuum.

Glaser, B. G. \& Strauss, A. L. (1967). The discovery of grounded theory. Chicago, IL: Aldine.

Gooden, A. R. (1996). Computers in the classroom. USA: Jossey-Bass and Apple Press.

Hayes, D., Christie, P., Mills, M., \& Lingard, B. (2004). Productive leaders and productive leadership: Schools as learning organisations. Journal of Educational Administration, 42(5), 520538.

Hayes, D. N. A. (2007). ICT and learning: Lessons from Australian classrooms. Computers $\mathcal{E}$ Education, 49(2), 385-395.

Hodgson, B. R. (1995). The roles and needs of mathematics teachers using IT. In D. Watson \& D. Tinsley (Eds.), Integrating information technology into education (pp. 27-37). London: Chapman \& Hall.

Jaber, W. E. \& Moore, D. M. (1999). A survey of factors which influence teachers' use of computer-based technology. International Journal of Instructional Media, 26(3).

Jacobsen, D. M. (2001). Building different bridges: Technology integration, engaged student learning, and new approaches to professional development. Paper presented at the 82nd Annual Meeting of the American Educational Research Association, Seattle, Washington. [verified 10 Oct 2010] http: / / people.ucalgary.ca/ dmjacobs/aera/building_bridges.html

Jacobsen, D. M. (2002). Building different bridges two: A case study of transformative professional development for student learning with technology. Paper presented at the 83rd Annual Meeting of the American Educational Research Association, New Orleans, Louisiana. [verified 10 Oct 2010]

http:/ / people.ucalgary.ca/ dmjacobs/aera/building_bridges_two.html

Jonassen, D. H. (2000). Revisiting activity theory as a framework for designing student-centred learning environments. In D. H. Jonassen \& S. M. Land (Eds.), Theoretical foundations of learning environments. New Jersey: Lawrence Erlbaum Associates.

Jonassen, D. H. \& Rohrer-Murphy, L. (1999). Activity theory as a framework for designing constructivist learning environments. Educational Technology Research \& Development, 47(1), 61-79.

Joyes, G. (2008). An activity theory approach to researching tutors' perceptions of effective online pedagogy. Educational Media International, 45(3), 231-243.

Jules Van Belle, G. C. \& Soetaert, R. (2001). Breakdown into the virtual user-involved design and learning. Journal of Technology and Teacher Education, 8(2), 31-42. 
Kuutti, K. (1996). Activity theory as a potential framework for human-computer interaction research. In A. N. Bonnie (Ed.), Context and consciousness: Activity theory and human-computer interaction. London, England: MIT Press.

Leithwood, K. A. \& Riehl, C. (2003). What we know about successful school leadership. Philadelphia: Laboratory for Student Success, Temple University. [verified 10 Oct 2010] http: / / eric.uoregon.edu/pdf/ whatweknow103.pdf

Manternach-Wigans, L. K. (1999). Computer technology integration in Iowa High schools: Perceptions of teachers. Unpublished Doctoral Dissertation, Iowa State University, Iowa.

Martin, W. B. (2000). Learning from the Colwell school: An ethnographic case study of an educational technology culture. Unpublished PhD, Cornell University.

Maykut, P., \& Morehouse, R. (2000). Beginning qualitative research: A philosophical and practical guide. London: Routledge Falmer.

McGarr, O. \& Kearney, G. (2009). The role of the teaching principal in promoting ICT use in small primary schools in Ireland. Technology, Pedagogy and Education, 18(1).

Means, B. \& Olson, K. (1997). Technology and education reform: Studies of education reform. Washington DC: Government Printing Office.

Morrison, G. R. \& Lowther, D. L. (2002). Integrating computer technology into the classroom (2nd ed.). New Jersey: Merrill Prentice Hall.

Morton, C. (1996). The modern land of Laputa. Phi Delta Kappan, 77(6), 416-419.

Moseley, D. \& Higgins, S. (1999). Ways forward with ICT: Effective pedagogy using information and communications technology (ICT) for literacy and numeracy in primary schools. United Kingdom: Newcastle University.

Murphy, E. \& Rodriguez-Manzanares, M. A. (2008). Using activity theory and its principle of contradictions to guide research in educational technology. Australasian Journal of Educational Technology, 24(4), 442-457. http:/ / www.ascilite.org.au/ajet/ ajet24/murphy.html

Nardi, B. A. (1997). Studying context: A comparison of activity theory, situated actions models, and distributed cognition. In A. N. Bonnie (Ed.), Context and consciousness: Activity theory and human-computer interaction. Cambridge: MIT Press.

OECD (2001). Learning to change: ICT in schools. Paris.

OTA (1995). Teachers and technology. Washington DC: Government Printing Office.

Pedretti, E., Mayer-Smith, J. \& Woodrow, J. (1999a). Teaming technology enhanced instruction in the science classroom and teacher professional development. Journal of Technology and Teacher Education, 7(2), 131-143.

Prain, V. \& Hand, B. (2003). Using new technologies for learning: A case study of a whole-school approach. Journal of Research on Technology in Education, 35(4), 441-458.

Selwyn, N., Dawes, L. \& Mercer, N. (2001). Promoting Mr 'Chips': the construction of the teacher/ computer relationship in educational advertising. Teaching and Teacher Education, 17, 3-14.

Senge, P., Cambron-McCabe, N., Lucas, T., Smith, B., Dutton, J. \& Kleiner, A. (2000). Schools that learn. New York: Doubleday. 
Sheingold, K. \& Hadley, M. (1990). Accomplished teachers: Integrating computers into classroom practice. New York: Bank Street College: Center for Technology in Education.

Shuldman, M. (2004). Superintendent conceptions of institutional conditions that impact teacher technology integration. Journal of Research on Technology in Education, 36(4), 319-343.

Stetson, R. \& Bagwell, T. (1999). Technology and teacher preparation: An oxymoron? Journal of Technology and Teacher Education, 7(2), 145-152.

Vanderlinde, R., Braak, J. v. \& Hermans, R. (2009). Educational technology on a turning point: Curriculum implementation in Flanders and challenges for schools. Educational Technology Research and Development, 57, 573-584.

Venezky, R. L. (2004). Technology in the classroom: steps toward a new vision. Education, Communication and Information, 4(1), 3-21.

Voulalas, Z. D. \& Sharpe, F. G. (2005). Creating schools as learning communities: Obstacles and processes. Journal of Educational Administration, 43(2), 187-208.

Wang, P., \& Chan, P. S. (1995). Advantages, disadvantages, facilitators and inhibitors of computer-aided instruction in Singapore's secondary schools. Computers $\mathcal{E}$ Education, 25(3), 151-162.

Yee, D. L. (2000). Images of school principals' information and communication technology leadership. Technology, Pedagogy and Education, 9(3).

Yin, R. K. (2003). Case study research: Design and methods (3 ed. Vol. 5). London: SAGE.

Zhao, Y. \& Cziko, G. A. (2001). Teacher adoption of technology: A perceptual control theory perspective. Journal of Technology and Teacher Education, 9(1), 5-30.

Dr Shanti Divaharan is an Assistant Professor at the Learning Sciences and Technologies Academic Group in the National Institute of Education, Nanyang Technological University, Singapore. Email: shanti.divaharan@nie.edu.sg Web: http:/ / eduweb.nie.edu.sg/LST/facultyandstaff/shanti.asp\#

Dr Lim Cher Ping is a Professor at the Department of Curriculum and Instruction in The Hong Kong Institute of Education, 10 Lo Ping Road, Tai Po, New Territories, Hong Kong SAR. Email: clim@ied.edu.hk

Web: http:/ / ied.academia.edu/CherPingLim/ About 